\title{
Computational Biology: IT Challenges and Opportunities
}

\author{
Stefan Unger, $\mathrm{PhD}^{*}$, and Andrew Komornicki, $\mathrm{PhD}$ \\ Sun Microsystems \\ Menlo Park, CA \\ USA \\ Phone: 1-650-786-0310 (80310) \\ $\{$ Stef an.Unger $\mid$ Andrew.Komornicki $\}$ @eng. sun.com
}

\begin{abstract}
We will survey the field of computational biology and discuss the many interesting computational challenges and opportunities in areas such as genomics, functional and structural genomics, pharmacogenomics, combinatorial chemistry/high throughput screening, and others of current interest.
\end{abstract}

